\title{
PENGARUH MODAL ASING TERHADAP RETURN ON INVESMENT MELALUI EKSPANSI
}

\author{
Effect of Foreign Capital Against Return On Investment Through Expansion
}

\author{
Bragas Rudesyana, Nurjanah Rahayuningsih \\ Manajemen FE Unwir \\ noerjanah.unwir@unwir.ac.id
}

\begin{abstract}
ABSTRAK
Objek penelitian pada permasalahan modal asing terhadap Roi melalui ekspansi pada CV. Dani Prima. Dari tahun 2008 sampai dengan tahun 2013 modal asing pada CV. Dani Prima mengalami kenaikan dan penurunan, Adapun rata-rata perkembangan modal asing sebesar Rp. 174.616.666, Ekspansi pada CV. Dani Prima, mengalami kenaikan, Adapun rata-rata perkembangan ekspansi sebesar Rp. 630.025 .000 dan Return on invesment (ROI) dari tahun 20082013 mengalami kenaikan dan penurunan. Adapun rata-rata perkembangan roi sebesar $25,37 \%$.
\end{abstract}

Hasil analisis statistik Dari perhitungan korelasi diatas maka diperoleh hasil koefisien korelasi X1 terhadap X2 sebesar 0,016 yang berarti koefisien korelasinya mempunyai hubungan yang sangat rendah dan positif. Sementara perhitungan koefisien determinasi maka diperoleh sebesar 0 , 02\%. Berarti kontribusi yang diberikan modal asing terhadap ekspansi mampu mencapai $0,02 \%$ dan sisanya $99,98 \%$ di pengaruhi faktor lain yang tidak diteliti. Berdasarkan hasil Uji hipotesis (t) maka nilai yang diperoleh thitung sebesar 0,032 digunakan uji dua pihak, dengan taraf signifikan 5\% dan derajat keabsahan (dk) 6-2 = 4 didapatkan nilai $T_{-}$tabel 2,776 karena $T_{-}$hitung $>T_{-}$(tabel 0,032 < 2,776), makaH_(1^o ) diterima danH_(1^a ) ditolak artinya tidak terdapat pengaruh modal asing terhadap ekspansi.

Sementara analisis korelasi ( $r$ ) pada variabel X2 terhadap Y diperoleh koefisien korelasi sebesar $-0,150$ yang berarti koefisien korelasinya mempunyai hubungan yang sangat rendah dan negatif. Perhitungan koefisien determinasi maka diperoleh sebesar 2, 25\%. Berarti kontribusi yang diberikan ekspansi terhadap return on invesment (ROI) mampu mencapai $2,25 \%$ dan sisanya 97, 75,\% dipengaruhi faktor lain yang tidak diteliti. Berdasarkan hasil Uji hipotesis (t) maka nilai yang diperoleh thitung sebesar $\mathbf{- 0 , 3 0 3}$ digunakan uji dua pihak, dengan taraf signifikan $5 \%$ dan derajat keabsahan (dk) 6-2 $=4$ didapatkan nilai $T_{-}$tabel 2,776 karena $T_{-}$hitung< $\ T \rrbracket$ tabel $(-0,303<$ 2,776), maka $H_{20}$ diterima $H_{-}\left(2^{\wedge} a\right)$ ditolak artinya tidak terdapat pengaruh ekspansi terhadap ROI.

Kata Kunci: Modal Asing, Return on Investmen, Ekspansi.

\section{ABSTRACT}

The object of research on the problem of foreign capital to Roi through the expansion of the CV. Dani Prima. From 2008 to 2013 foreign capital in the CV. Dani Prima has increased and decreased, The average development of foreign capital is $\mathbf{R p}$. 174,616,666, Expansion in CV.Dani Prima, has increased, The average expansion of the development of Rp. 630,025,000 and Return on Investment (ROI) from 2008-2013 increased and decreased. The average development of ROI is $25.37 \%$.

Statistical analysis results From the correlation calculation above we get the correlation coefficient $\mathrm{X} 1$ to $\mathrm{X} 2$ of 0.016 which means the correlation coefficient has a very low and positive relationship. while calculating the coefficient of determination is obtained at $0.02 \%$. This means that the contribution of foreign capital to expansion can reach $0.02 \%$ and the remaining $99.98 \%$ is influenced by other factors not examined. Based on the results of the hypothesis test $(t)$, the value obtained tcount of 0.032 used a two-party test, with a significance level of $5 \%$ and the degree of validity (dk) 6-2 = 4 obtained $T_{-}$table value 2.776 because $T_{-}$count $>T_{-}$(table) $\left.0.032<2.776\right)$, then $H_{-}\left(1^{\wedge}\right.$ o $)$ is accepted and $H_{-}\left(1^{\wedge} a\right)$ is rejected, meaning that there is no influence of foreign capital on expansion.

While correlation analysis ( $r$ ) on the variable $X 2$ to Y obtained a correlation coefficient of $\mathbf{- 0 . 1 5 0}$ which means the correlation coefficient has a very low and negative relationship. calculation of the coefficient of determination is obtained by $2.25 \%$. It means that the contribution given by expansion to return on investment (ROI) is able to reach $2.25 \%$ and the remaining $97.75, \%$ is influenced by other factors not examined. Based on the results of the hypothesis test $(t)$, the value obtained $t$-count of -0.303 used a two-party test, with a significance 
level of 5\% and the degree of validity (dk) 6-2 = 4 obtained $T$-value 2,776 because $T$-count $\langle\llbracket T \rrbracket$ table $(-0,303)<2,776)$, then $\mathrm{H}_{2} \mathrm{o}$ is accepted $\mathrm{H}_{-}\left(2^{\wedge} \mathrm{a}\right)$ is rejected, meaning that there is no expansion effect on ROI.

Keywords: Foreign Capital, Return On Investments, Expansion.

\section{PENDAHULUAN}

Dalam rangka menjalankan operasional perusahaan, setiap perusahaan membutuhkan adanya modal untuk membiayai kegiatan operasional tersebut, sumber modal dalam perusahaan terdiri dari sumber internal dan sumber eksternal. Ketika perusahaan membutuhkan modal maka modal yang digunakan yaitu bisa berasal dari sumber intern. Tetapi apabila modal intern tidak cukup untuk membiayai kegiatan perusahaan maka perusahaan dapat menggunakan modal ekstern sebagai solusi untuk pembiayaan kegiatan perusahaan, yaitu dengan meminjam kepada pihak luar perusahaan (modal asing).

Modal Asing adalah modal yang berasal dari luar perusahaan atau meminjam dari pihak luar perusahaan yang sifatnya sementara bekerja dalam perusahaan dan bagi perusahaan tersebut merupakan utang, yang pada akhirny aharus dibayar kembali. Modal asing mempunyai peranan penting bagi perusahaan yaitu dengan adanya modal asing, perusahaan dapat membiayai segala kebutuhan produksi perusahaan dan juga untuk memperluas perusahaan (ekspansi).

Ekspansi merupakan salah satu tujuan dari setiap perusahaan, karena dengan melakukan ekspansi maka eksistensi perusahaan dapat semakin diakui dan tujuan jangka panjang perusahaan dapat tercapai. Setiap perusahaan pasti merencanakan perluasan usaha (ekspansi), untuk melakukan ekspansi manager perusahaan perlu menganalisis perkembangan kondisi perusahaan dan membutuhkan perhitungan yang cermat, tepat dan matang. Agar perusahaan tidak salah langkah dalam melaksanakan ekspansi. Dengan melakukan ekspansi maka kemampuan perusahaan dalam menghasilkan keuntungan Akan ikut meningkat, karena tujuan utama perusahaan bukan hanya mempertahankan hidup usahnya saja. Tetapi hal lain yang harus menjadi perhatian adalah kemampuan perusahaan dalam menghasilkan Pofitabilitas perusahaan.

Return on investment (ROI) adalah merupakan pengukuran kemampuan perusahaan secara keseluruhan di dalam menghasilkan keuntungan dengan jumlah keseluruhan aktiva yang tersedia di dalam perusahaan. Dengan Rasio ini perusahaan dapat mengukur seberapa banyak laba bersih yang bisa diperoleh dari seluruh dari seluruh kekayaan yang dimiliki perusahaan. Dengan melihat sejauh mana investasi yang telah ditanamkan mampu memberikan pengembalian keuntungan sesuai dengan yang diharapkan.

Identifikasi Masalah Penelitian 
Berdasar kan uraian latar belakang penelitian tersebut peneliti dapat mengidentifikasi masalah yang ada sebagai berikut:

1. Apa saja kendala dalam melaksanakan ekspansi pada CV. Dani Prima.

2. Seberapa besar nilai Return on Investment (ROI) pada CV. Dani Prima.

3. Bagaimana perkembangan Return on Investment (ROI) pada CV. Dani Prima

4. Faktor apa saja yang mempengaruhi profitabilitas pada CV. Dani Prima.

5. Berapa besar pengaruh modal asing terhadap ekspansi pada CV. Dani Prima

6. Berapa besar pengaruh ekspansi terhadap Return on Investment(ROI) pada CV. Dani Prima.

\section{TINJAUAN PUSTAKA}

\section{Modal Asing}

Untuk mendukung pencapaian tujuan perusahaan diperlukan adanya modal yang cukup. Modal merupakan salah satu kebutuhan yang sangat penting bagi perusahaan karena untuk menjalankan suatu usaha diperlukan adanya Dana yang Akan digunakan untuk membiayai berbagai kegiatan operasional perusahaan, modal diperoleh dari pemilik perusahaan maupun dari utang. Bagi perusahaan sumber dana / modal yang berasal dari para kreditur tersebut ialah disebut modal asing.

Menurut Kasmir (2008:46), menyatakan bahwa:"Modal asing merupakan kewajiban atau utang perusahaan kepada pihak lain karena memperoleh pinjaman (kredit).

$$
\text { Menurut Najmudin }
$$
menyatakan bahwa: "Modal asing adalah modal yang berasal dari luar perusahaan yang sifatnya sementara dioperasikan dalam perusahaan. Modal tersebt bagi perusahaan merupakan kewajiban yang pada saatnya harus dibayar kembali."

Menurut Sutrisno (2009:08) menyatakan bahwa: "Modal asing adalah modal yang berasal dari pinjaman bank, lembaga keuangan, maupun mengeluarkan surat utang dan atas penggunaan sumber dana ini dalam perusahaan harus memberikan kompensasi berupa bunga yang menjadi beban tetap perusahaan".

Dari beberapa pendapat ahli tersebut dapat disimpulkan bahwa modal asing adalah modal yang berasal dari luar perusahaan yang sifatnya sementara bekerja dalam perusahaan serta perusahaan wajib memberikan kompensasi berupa jasa/bunga.

\section{Jenis - Jenis Modal Asing}

Banyak penulis dalam pembelanjaan yang membagi modal asing atau utang dalam 3 golongan. Menurut Bambang Riyanto (2010:227), yang menyatakan bahwa:

\section{Modal Asing/Utang Jangka Pendek (short-term debt)}

Sebagaimana diuraikan di atas bahwa modal asing (utang atau kredit) jangka pendek adalah modal asing yang jangka waktunya paling lama satu tahun. 
Sebagian besar utang jangka pendek terdiri dari kredit perdagangan, yaitu kredit yang diperlukan untuk dapat menyelenggarakan usahanya. Adapun jenis-jenis modal asing (utang atau kredit) jangka pendek yang terutama adalah:

1. Kredit Rekening Koran.

2. Kredit dari penjual (Leverancier crediet).

3. Kredit dari pembeli (Afnemers crediet).

4. Kredit wesel.

\section{Modal Asing/ Utang Jangka} Menengah (Intermediate-Term

\section{Debt)}

Sebagaimana diuraikan di muka, modal asing atau utang jangka menengah adala utang yangjangka waktu atau umumnya adalah lebih dari satu tahun dan kurang dari 10 tahun. Kebutuhan membelanjai usaha dengan jenis kredit ini dirasakan karena adanya kebutuhan yang tidak dapat dipenuhi dengan kredit jangka pendek di satu pihak dan juga sukar untuk dipenuhi dengan kredit jangka panjang di lain pihak. Untuk kebutuhan modal yang tidak begitu besar jumlahnya juga tidak ekonomis untuk dipenuhi dengan dana yang berasal dari pasar modal. Lagi pula pengurusan pembelanjaannya adalah lebih mudah dengan mengadakan kontak langsung dengan pihak yang meminjam atau kreditur, dan cara ini adalah ciri khas dari pembelanjaan dengan "intermediate-term debt.

Bentuk-bentuk utama dari kredit jangka menengah adalah: 1) Term Loan, dan 2) Lease financing.

\section{1. "Term Loan"}

"Term loan" adalah kredit usaha dengan umur lebih dari satu tahun dan kurang dari 10 tahun. Pada umumnya term loan dibayar kembali dengan angsuran tetap selama satu periode tertentu (amortization payments), misalkan pembayaran angsuran dilakukan setiap bulan, setiap kuartal atau setiap tahun.

\section{Leasing}

Bentuk lain dari "intermediate-term debt" adalah "Leasing". Apabila kita tidak ingin memiliki suatu aktiva, tetapi hanya menginginkan "service" dari aktiva tersebut, kita dapat memperoleh "hak penggunaan" atas semua aktiva itu tanpa disertai dengan hak milik, dengan cara mengadakan kontrak "leasing" untuk aktiva tersebut.

Dengan demikian leasing adalah suatu alat atau cara untuk mendapatkan "service" dari suatu aktiva tetap yang pada dasarnya adalah sama seperti halnya kalau 
Riri Nur Fajriah, Fitria Damayanti

kita menjual obligasi untuk mendapatkan "service" dan hak milik atas aktiva tersebut dan bedanya pada leasing tidak disertai dengan hak milik.

Ada tiga bentuk utama dari leasing, yaitu:

1) "Sale and Leaseback"

2) "services Lesaes atau “Operating Leases"dan

3) "Financial Leases"

\section{Modal Asing/Utang Jangka Panjang} (Long-term debt)

Modal asing/utang jangka panjang adalah utang yang jangka waktunya adalah panjang, umumnya lebih dari 10 tahun.

Adapun jenis atau bentuk-bentuk utama dari Utang jangka panjang antara lain:

\section{Pinjaman obligasi (Bonds- payables)}

Pinjaman obligasi adalah pinjaman uang untuk jangka waktu yang panjang. Jangka waktu pinjaman obligasi hendaknya didasarkan kepada pertimbangan-pertimbangan sebagai berikut:

1. Jangka waktu pinjaman kredit hendaknya disesuaikan dengan jangka waktu penggunaannya di dalam perusahaan.
2. Jumlah angsuran harus disesuaikan dengan jumlah penyusutan dari aktiva tetap yang akan dibelanjai dengan kredit obligasi tersebut.

Pelunasan atau pembayaran kembali pinjaman obligasi dapat diambil dari:

1. Penyusutan aktiva tetap yang dibelanjai dengan pinjaman obligasi tersebut.

2. Keuntungan.

Jenis-jenis obligasi antara lain ialah:

\section{i. Obligasi biasa (Bonds)}

Obligasi biasa adalah obligasi yang bunganya tetap dibayar oleh debitur dalam waktu-waktu tertentu, dengan tidak memandang apakah debitur memperoleh keuntungan atau tidak.

ii. Obligasi pendapatan (Income Bonds) Income bonds adalah jenis obligasi di mana pembayaran bunga hanya dilakukan pada waktu-waktu debitur atau perusahaan yang mengeluarkan surat obligasi tersebut mendapatkan keuntungan.

iii. Obligasi yang dapat ditukarkan (Convertible Bonds)

Convertible bonds adalah obligasi yang memberikan kesempatan kepada pemegang surat obligasi tersebut untuk pada suatu saat tertentu menukarkannya dengan 
saham dari perusahaan yang bersangkutan.

\section{Pinjaman Hipotik (Mortgage)}

Pinjaman hipotik adalah pinjaman jangka panjang di mana pemberi uang (kreditur) diberi hak hipotik terhadap suatu barang tidak bergerak, agar supaya bila pihak debitur tidak memenuhi kewajibannya, barang itu dapat dijual dan dari hasil penjualan tersebut dapat digunakan untuk menutupi tagihannya.

\section{Faktor - Faktor Yang Mempengaruhi Perubahan Modal}

Modal yang dibutuhkan perusahaan harus segera terpenuhi sesuai dengan kebutuhan perusahaan. Namun, terkadang untuk memenuhi kebutuhan modal seperti yang diinginkan tidaklah selalu tersedia. Hal ini disebabkan terpenuhi tidaknya kebutuhan modal sangat tergantung kepada keadaan perusahaan tersebut karena itu pihak manajemen dalam menjalankan kegiatan operasi perusahaan terutama kebijakan dalam upaya pemenuhan modal harus selalu memperhatikan faktor-faktor tersebut.

Menurut Malayu S.P. Hasibun (2006:63), faktor-faktor yang menyebabkan perubahan modal adalah:

1. Adanya kenaikan sektor modal baik yang berasal dari laba maupun adanya peneluaram modal saham atau tambahan investasi dari pemilik perusahaan maka modal akan bertambah.
2. Ada pengurangan atau penurunan aktiva tetap yang diimbangi dengan bertambahnya aktiva lancar karena adanya penjualan aktiva tetap maupun melalui proses depresiasi, modal akan bertambah.

3. Ada penambahan hutang jangka panjang baik dalam bentuk obligasi, hipotek, atau hutang jangka panjang lainya yang diimbangi dengan bertambahnya aktiva lancar, maka modal akan bertambah.

4. Karena adanya kerugian yang diderita oleh perusahaan, baik kerugian normal maupun kerugian exidentil, maka akan mengurangi modal.

5. Adanya penambahan atau pembelian aktiva tetap maka akan mengurangi modal

6. Pengambilan uang yang dilakukan oleh pemilik perusahaan untuk kepentingan pribadi.

Perubahan modal kebutuhan modal sangat tergantung kepada keadaan perusahaan tersebut karena itu pihak manajemen dalam menjalankan kegiatan operasi perusahaan terutama kebijakan dalam upaya pemenuhan modal harus selalu memperhatikan faktorfaktor tersebut, Makin besar kebutuhan dana untuk membelanjai kebutuhannya maka perusahaan tersebut makin cenderung untuk menahan sebagian besar dari keuntungan yang diperoleh.

\section{Ekspansi}

Tujuan dari perusahaan yaitu untuk mendapatkan keuntungan dari setiap usaha 
yang dikembangkannya.Agar perusahaan tetap bertahan dan hidup dalam jangka waktu yang panjang perusahaan perlu mengembangkan usahanya baik dalam bentuk perluasan aktiva tetap maupun berupa peningkatan hasil produksinya, hal ini yang dinamakan sebagai ekspansi.

Menurut Bambang Riyanto (2010 : 301) menyatakan bahwa : "Ekspansi adalah perluasan dari pada modal, baik perluasan modal kerja saja, atau modal kerja dan modal tetap, yang digunakan secara tetap dan terus-menerus di dalam perusahaan".

Menurut Suad Husnan dan Enny Pudjiastuti (2012 : 395) menyatakan bahwa :"Ekspansi yaitu perluasan usaha yang dapat dilakukan dengan cara menambah kapasitas pabrik, menambah unit produksi, menambah devisi baru, dan dapat juga dilakukan dengan menggambungkan dengan usaha yang telah ada (merger dan consolidation) atau membeli perusahaan yang telah ada (akuisisi)”.

Menurut R. Agus Sartono (2008: 365) menyatkan bahwa: "Apabila perusahaan memperluas usahanya dengan cara menambah kapasitas produksi atau mendirikan perusahaan baru maka cara ini disebut dengan ekspansi”.

Dari definisi diatas dapat diambil kesimpulan bahwa ekspansi adalah perluasan usaha yang dilakukan baik menambahkan aktiva tetap maupun penambahan kapasitas produksi perusahaan yang tak lain bertujuan untuk memapankan perusahaan.
Menurut Bambang Riyanto (2010:304), menyatakan bentuk-bentuk ekspansi antara lain:

a. Ekspansi usaha (business expansion) Ekspansi usaha ekspansi yang dilakukan tanpa mengakibatkan perubahan struktur modal, jadi perusahaan hanya menambah modal kerjanya saja dengan menggunakan kapasitas produksi yang tersedia di dalam perusahaan.

b. Ekspansi finansial (financial expansion)

Ekspansi financial ekspansi yang di jalankan dengan membeli alat produksi tahan lama.memodernisir alat-alat yang produksi lama mendirikan pabrik baru,mendirikan pabrik baru. Mengambil alih perusahaan lain, penggabungan dengan perusahaan lain bentuk ekspansi ini membutuhkan tambahan modal jangka panjang, sehingga mengakibatkan perubahan struktur modal.

Dengan demikian bentuk - bentuk ekspansi menurut Bambang Riyanto di bagi dua macam yaitu ekspansi usaha (business expansion) dan ekspansi financial (financial expansion).

\section{Sumber-Sumber Pembelanjaan Ekpansi}

Untuk memperbesar output di perlukan tambahan modal kerja untuk membeli tambahan bahan dasar, bahan pembantu, biaya penyimpanan di gudang, upah buruh, 
tambahan kredit pembeli untuk penjual bahan mentah, biaya penyimpanan hasil akhir di gudang, kredit penjual untuk para pelanggan. Kebutuhan tambahan modal kerja pada tingkat ekspansi ini dipenuhi, atau dengan kata lain bagaimana Cara membelanjanya.

Menurut Bambang Riyanto (2010:307), yang menyatakan bahwa sumber-sumber pembelanjaan ekspansi berangsur-angsur adalah sebagai berikut:

1. Sumber Intern

Sumber intern ialah Dana yang berasal atau dibentuk di dalam perusahaan sendiri, yaitu:

a. Cadangan untuk ekspansi

b. Laba

c. Akumulasi penyusutan

2. Sumber Ekstern

Sumber ekstern ialah Dana yang berasal dari luar perusahaan. Sumber ekstern yang diperlukan untuk membelanjai bentuk ekspansi ini ialah:

a. Kredit dari penjual (leveranciers crediet)

b. Kredit dari Bank

\section{Motif-motif Ekspansi}

Suatu perusahaan dalam melaksanakan ekspansinya memiliki dorongan atau motivasi tertentu. Dororngan untuk ini tidak semata-mata untuk mendapatkan keuntungan yang sebesar-besarnya, melainkan karena adanya keinginan untuk memperoleh prestasi yang lebih tinggi.
Menurut Bambang Riyanto (2010: 301) terdapat dua motif ekspansi antara lain:

1. Motif Ekonomi

Yaitu apabila ekspansi suatu perusahaan didasarkan pada pertimbangan untuk menstabilisir ekspansi usaha yang diperoleh.

2. Motif Psychologis

Yaitu ekspansi yang didasarkan pada personal ambition dari pemilik atau pimpinan perusahaan untuk memperoleh prestige dan kekuasaan yang lebih besar.

Berdasarkan uraian diatas dapat disimpulkan bahwa motif-motif ekspansi yaitu terdiri dari motif ekonomi dan motif psychologis.

\section{Return on Invesment (ROI)}

Beberapa ahli berpendapat mengenai Return on Investment (ROI), diantaranya:

Menurut Lukman Syamsudin (2009:63) Menyatakan bahwa:

"Return On Investment merupakan pengukuran kemampuan perusahaan secara keseluruhan di dalam menghasilkan keuntungan dengan jumlah keseluruhan aktiva yang tersedia di dalam perusahaan."

Menurut Irham Fahmi

(2013:82)

Menyatakan bahwa: adalah:

"Rasio yang digunakan untuk melihat sejauh mana investasi yang telah ditanamkan maтри memberikan pengembalian keuntungan sesuai dengan yang diharapkan" Menurut Sutrisno

(2012:223) 
mengemukakan: "Return on Investment (ROI) adalah kemampuan perusahaan untuk menghasilkan keuntungan yang akan digunakan untuk menutup investasi yang dikeluarkan. Laba yang digunakan untuk mengukur rasio ini adalah laba bersih setelah pajak atau EAT.”

Berdasarkan definisi-definisi diatas maka dapat disimpulkan bahwa Return on Invesment adalah kemampuan perusahaan dalam menghasilkan laba atas investasi yang telah diterima oleh perusahaan.

Menurut Munawir (2010:89), besarnya Return on Investment dipengaruhi oleh dua faktor:

1. Turnover dari operating assets (tingkat perputaran aktiva yang digunakan untuk operasi), yaitu kecepatan berputarnya operating assets dalam suatu periode tertentu. Cara meningkatkan tingkat perputaran ivestasi, yaitu dengan meningkatkan volume penjualan dengan jumlah invertasi yang sama, atau menurunkan atau mengurangi jumlah investasi untuk memperoleh volume penjualan tertentu. Turnover tersebut dapat ditentukan dengan membagi net dengan "operating assets."

2. Profit Margin, yaitu keuntungan operasi yang dinyatakan dalam prosentase dan jumlah penjualan bersih, profit margin ini mengukur tingkat keuntungan yang dapat dicapai oleh perusahan dihubungkan dengan penjualan.
Besarnya Return on Investment (ROI) akan berubah kalau ada perubahan profit margin atau assets turnover, baik masingmasing ataupun kedua-duanya. Dengan demikian maka pimpinan perusahaan dapat menggunakan salah satu atau kedua-duanya dalam rangka usaha untuk memperbesar. profit margin adalah bersangkutan dengan usaha untuk mempertinggi efesisnsi di sektor produksi, penjualan dan administrasi. Usaha mempertinggi ROI dengan memperbesar assets turnover adalah kebijaksanaan investasi dana dalam berbagai aktiva, baik aktiva lancar maupun aktiva tetap.

\section{Perhitungan Return on Invesment}

ROI digunakan untuk mengukur kemampuan modal yang diinvestasikan dalam aktiva tidak lancar ditambah modal kerja untuk menghasilkan keuntungan bersih. ROI adalah alat ukur yang sangat umum digunakan untuk mengukur kinerja sebuah pusat investasi.

Bambang Riyanto (2009:336)

menyebutkan, Return on Investment adalah:

ROI $==\frac{\text { Laba Sesudah Pajak }}{\text { Jumlah Aktiva }} \times 100 \%$
1. Laba sesudah pajak (EAT)
2. Total aset
Penjelasan indikator:
1. Laba sesudah pajak (EAT)
Merupakan keuntungan yang didapat
oleh perusahaan setelah dikurangi
pajak.

2. Total aktiva 
Jumlah keseluruhan aktiva atau harta yang dimiliki oleh perusahaan.

\section{Menurut Bambang Riyanto (2010:}

308) menyatakan bahwa: "Sumber eksternal ialah dana yang berasal dari perusahaan.

Sumber eksternal ini diperlukan untuk membelanjai bentuk - bentuk ekspansi”.

Melihat penjelasan di atas, sudah jelas bahwa terdapat hubungan antara modal asing dengan ekspansi, sebab untuk meningkatkan produksi dan memperluas usahanya yang dilakukan perusahaan selalu membutuhkan tambahan modal yang besar dan sangat dibutuhkan. Modal tersebut tidak saja bersumber dari dalam tetapi juga dari luar perusahaan atau yang disebut dengan modal asing.

Dengan melakukan ekspansi maka perusahaan akan dapat memperluas pasarnya, semakin luas pasar maka semakin bertambah pula keuntungan yang diperoleh perusahaan. Karena tujuan perusahaan diantaranya memperoleh laba yang maksimal. Dimana laba dapat dijadikan sebagai tolak ukur keberhasilan suatu perusahaan dalam menjalankan usahanya.

Menurut Bambang Riyanto (2010 :302)menyatakan bahwa: "Makin luasnya pasar bagi produknya mendororng perusahaan tersebut untuk memperbesar produksinya untuk mengimbangi tambahan permintaan atau tambahan luasnya pasar bagi produksinya.Makin besarnya jumlah produksi yang dapat dijual, berarti makin besar kemungkinan untuk mendapatkan laba yang lebih besar, sehingga dengan demikian setiap pemimpin perusahaan mempunyai harapan dan keinginan untuk dapat selalu mengembangkan dan meluaskan perusahaannya".

Berdasarkan pernyataan tersebut maka dapat disimpulakan bahwa dengan adanya laba yang maksimal seperti yang ditargetkan perusahaan, maka perusahaan bisa melakukan perluasan usaha (ekspansi). Dengan adanya ekspansi tersebut perusahaan bisa mendapatkan laba yang lebih besar.

\section{Hipotesis Penelitian}

Berdasarkan kerangka pemikiran serta latar belakang yang telah diuraikan di atas, maka hipotesis penelitian tersebut dapat dinyatakan sebagai berikut:

$H_{1}$ : Terdapat pengaruh antara modal asing terhadap ekspansi

$H_{2}$ : Terdapat pengaruh antara ekspansi terhadap return on investment

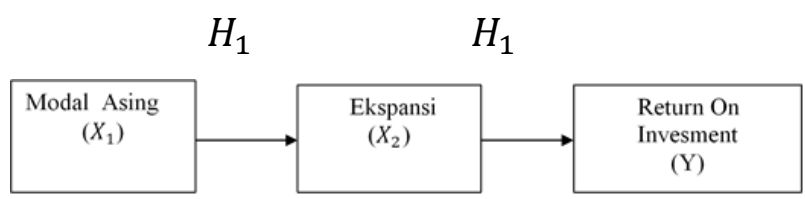

\section{METODOLOGI PENELITIAN}

Metode yg digunakan dalam penelitian ini adalah metode deskiptif dan metode asosiatif. dalam penelitian ini populasinya adalah modal asing, ekspansi dan return on invesment yang diperoleh dengan cara menganalisis laporan laba rugi dan neraca perusahaan yang dibuat dari tahun 2007 
sampai dengan sekarang di Perusahaan CV.

Dani Prima.

Adapun penjabarannya dapat dijelaskan sebagai berikut:

Tabel

Indikator Variabel Dan Pengukuran

\begin{tabular}{|c|c|c|}
\hline Variabel & Indikator & Pengukuran \\
\hline $\begin{array}{l}\text { Independent } \\
\text { Modal Asing }\left(?_{1}\right)\end{array}$ & $\begin{array}{l}\text { 1. Hutang jangka panjang } \\
\text { 2. Hutang jangka menengah } \\
\text { 3. Hutng jangka pendek } \\
\text { Najmudin (2011:218) }\end{array}$ & Rasio \\
\hline $\begin{array}{l}\text { Intervening } \\
\text { Ekspansi (X2) }\end{array}$ & $\begin{array}{l}\text { 1. Penambahan modal kerja } \\
\text { 2. Penambahan modal tetap } \\
\text { Bambang Riyanto ( } 2010 \\
\text { :301) }\end{array}$ & Rasio \\
\hline $\begin{array}{l}\text { Dependent } \\
\text { Return On Invesment } \\
\text { (ROI) (??) }\end{array}$ & $\begin{array}{l}\text { 1. EAT } \\
\text { 2. Total Asset } \\
\text { Sutrisno (2012:223) }\end{array}$ & Rasio \\
\hline
\end{tabular}

\section{HASIL DAN PEMBAHASAN}

\section{Hasil Penelitian}

Kondisi Keuangan pada Perusahaan CV. Dani Prima

Modal merupakan faktor penting yang harus dipenuhi oleh setiap perusahaan dalam menjalankan suatu kegiatan usahanya, modal berperan penting dalam menjamin kelangsungan usaha. Adapun kondisi modal sendiri dan Aktiva Lancar pada Perusahaan CV. Dani Prima adalah pada tabel di bawah ini:

Tabel

Kondisi Modal Sendiri dan Aktiva Lancar Pada CV. Dani Prima

Tahun 2008 - 2013

\begin{tabular}{|c|c|c|}
\hline Tahun & $\begin{array}{c}\text { Modal } \\
\text { Sendiri } \\
\text { (Rp) }\end{array}$ & $\begin{array}{c}\text { Aktiva } \\
\text { Lancar } \\
(\mathbf{R p})\end{array}$ \\
\hline 2008 & 343.600 .000 & $(\mathrm{Rp})$ \\
\hline
\end{tabular}

\begin{tabular}{|l|l|l|}
\hline 2009 & 398.126 .000 & 110.700 .000 \\
\hline 2010 & 447.174 .000 & 118.026 .000 \\
\hline 2011 & 458.350 .000 & 120.974 .000 \\
\hline 2012 & 510.100 .000 & 231.250 .000 \\
\hline 2013 & 575.100 .000 & 232.300 .000 \\
\hline
\end{tabular}

Tabel

Kondisi Total Aktiva dan Laba

Pada CV. Dani Prima

Tahun 2008 - 2013

\begin{tabular}{|c|c|c|}
\hline Tahun & $\begin{array}{c}\text { Total aktiva } \\
(\mathbf{R p})\end{array}$ & L/R (Rp) \\
\hline 2008 & 559.100 .000 & 133.600 .000 \\
\hline 2009 & 567.026 .000 & 145.126 .000 \\
\hline 2010 & 570.974 .000 & 160.174 .000 \\
\hline 2011 & 682.250 .000 & 167.550 .000 \\
\hline 2012 & 684.300 .000 & 172.000 .000 \\
\hline 2013 & 716.500 .000 & 179.600 .000 \\
\hline
\end{tabular}

\section{Pembahasan}

Pada bagian ini akan menjelaskan tentang perkembangan Modal Asing, Ekspansi dan ROI pada CV. Dani Prima selama tujuh tahun yaitu dari tahun 2007 sampai dengan 2013, adapun pembahasan yang lebih jelasnya sebagai berikut:

Modal Asing Pada CV Dani Prima

Dibagian ini akan membahas mengenai perkembangan Modal asing yang terdapat pada CV. Dani dari tahun 2007 sampai 2013, adapun kondisi modal asing pada CV Dani Prima ada pada tabel dibawah ini:

Tabel

Kondisi Modal Asing Atau Total Hutang Pada CV. Dani Prima

Tahun 2007 - 2013 


\begin{tabular}{|c|l|c|}
\hline Tahun & $\begin{array}{c}\text { Total Hutang } \\
(\mathbf{R p})\end{array}$ & $\begin{array}{c}\text { Naik/ Turun } \\
(\mathbf{R p})\end{array}$ \\
\hline 2007 & 122.600 .000 & - \\
\hline 2008 & 215.500 .000 & 92.900 .000 \\
\hline 2009 & 168.900 .000 & $(46.600 .000)$ \\
\hline 2010 & 123.800 .000 & $(45.100 .000)$ \\
\hline 2011 & 223.900 .000 & 100.100 .000 \\
\hline 2012 & 174.200 .000 & $(49.700 .000)$ \\
\hline 2013 & 141.400 .000 & $(32.800 .000)$ \\
\hline Jumlah & $\mathbf{1 . 1 7 3 . 0 0 0 . 0 0 0}$ & \\
\hline Mean & $\mathbf{1 6 7 . 5 7 1 . 4 2 8}$ & \\
\hline
\end{tabular}

Ekspansi Pada CV. Dani Prima

Untuk perkembangan ekspansi dalam perkembangannya dapat dilihat dari bertambahnya modal kerja dan bertambahnya modal tetap pada CV. Dani Prima dalam kegiatan usaha selama tujuh tahun dari tahun 2007 sampai 2013 adalah sebagai berikut :

Tabel

Perkembangan Ekspansi Pada CV. Dani Prima

Tahun 2007-2013

(Dalam Ribuan)

\begin{tabular}{|c|c|c|c|c}
\hline $\mathbf{N}$ & $\begin{array}{c}\text { Modal } \\
\text { Kerja } \\
\text { (Rp) }\end{array}$ & $\begin{array}{c}\text { Modal } \\
\text { Tetap } \\
\text { (Rp) }\end{array}$ & $\begin{array}{c}\text { Jumlah } \\
\text { Modal } \\
\text { Kerja\&Modal } \\
\text { Tetap } \\
\text { (Rp) }\end{array}$ & $\begin{array}{c}\text { Total } \\
\text { Hutang/ } \\
\text { Modal } \\
\text { Asing } \\
\text { (Rp) }\end{array}$ \\
\hline 2007 & 103.000 & 208,000 & 311.000 & 122.600 .000 \\
\hline 2008 & 110.700 & 448.400 & 559.100 & 215.500 .000 \\
\hline 2009 & 118.026 & 449.000 & 567.026 & 168.900 .000 \\
\hline 2010 & 120.974 & 450.000 & 570.974 & 123.800 .000 \\
\hline 2011 & 231.250 & 451.000 & 682.250 & 223.900 .000 \\
\hline 2012 & 232.300 & 452.000 & 684.300 & 174.200 .000 \\
\hline 2013 & 263.500 & 453.000 & 716.500 & 141.400 .000 \\
\hline
\end{tabular}

Return On Invesment Pada CV. Dani Prima

Bagian ini membahas mengenai kondisi profitabilitas pada CV. Dani Prima selama enam tahun yaitu dari tahun 2008 sampai tahun 2013. Dalam analisis profitabilitas ini menggunakan ROI (Return On Invesment)

yaitu perbandingan antara laba setelah pajak dengan total aset. Berdasarkan data yang diperoleh dari neraca dan laporan rugi laba, didapat jumlah total aset dan laba setelah pajak (EAT) untuk digunakan dalam penghitungan profitabilitas. Adapun perkembangan total aset dan EAT sebagai berikut :

Tabel

Data Total Aset dan EAT

CV. Dani Prima

Tahun 2008 - 2013

\begin{tabular}{|c|c|c|c|}
\hline Tahun & Total Aset & EAT & ROI (\%) \\
\hline 2008 & 559.100 .000 & 133.600 .000 & 23,89 \\
\hline 2009 & 567.026 .000 & 145.126 .000 & 25,59 \\
\hline 2010 & 570.974 .000 & 160.174 .000 & 28,05 \\
\hline 2011 & 682.250 .000 & 167.550 .000 & 24,55 \\
\hline 2012 & 684.300 .000 & 172.000 .000 & 25,13 \\
\hline 2013 & 716.500 .000 & 179.600 .000 & 25,06 \\
\hline
\end{tabular}

$\mathrm{ROI}=\frac{E A T}{\text { Total Assets }} \times 100 \%$

ROI tahun $2008: \frac{133.600 .000}{559.100 .000} \times 100 \%=23,89 \%$

ROI tahun $2009: \frac{145.126 .000}{567.026 .000} \times 100 \%=25,59 \%$

ROI tahun $2010: \frac{160.174 .000}{570.974 .000} \times 100 \%=28,05 \%$

ROI tahun $2011: \frac{167.550 .000}{682.250 .000} x 100 \%=24,55 \%$

ROI tahun $2012: \frac{172.000 .000}{684.300 .000} \times 100 \%=25,13 \%$

ROI tahun 2013: $\frac{179.600 .000}{716.500 .000} \times 100 \%=25,06 \%$

\section{Analisis Data}

Analisis Korelasi $\mathrm{X}_{1}$ (Modal Asing) terhadap $\mathrm{X}_{2}$ (Ekspansi)

\begin{tabular}{|c|c|c|c|c|c|}
\hline $\mathbf{n}$ & $\mathbf{X}_{\mathbf{1}}$ & $\mathbf{X}_{\mathbf{2}}$ & $\mathbf{X . X}_{\mathbf{2}}$ & $\mathbf{X 1}^{\mathbf{2}}$ & $\mathbf{X}_{\mathbf{2}}{ }^{2}$ \\
\hline 1 & 215 & 559 & 120,187 & 46.225 & 312.481 \\
\hline 2 & 168 & 567 & 95,256 & 28.224 & 321.489 \\
\hline 3 & 123 & 570 & 70,110 & 15.129 & 324.900 \\
\hline 4 & 223 & 682 & 152,086 & 49.729 & 465.124 \\
\hline 5 & 174 & 684 & 119,016 & 30.276 & 467.856 \\
\hline 6 & 141 & 716 & 100,956 & 19.881 & 512.656 \\
\hline$\Sigma$ & $\mathbf{1 . 0 4 4}$ & $\mathbf{3 . 7 7 8}$ & $\mathbf{6 5 7 . 6 1 1}$ & $\mathbf{1 8 9 . 4 6 4}$ & $\mathbf{2 4 . 0 4 5 . 0 6}$ \\
\hline
\end{tabular}


$\mathrm{r}=\frac{n \Sigma X \mathrm{X}_{2}-(\Sigma X)\left(\Sigma \mathrm{X}_{2}\right)}{\sqrt{\left(n \Sigma X^{2}-(\Sigma X)^{2}\right)\left(n \Sigma \mathrm{X}_{2}^{2}-\left(\Sigma \mathrm{X}_{2}\right)^{2}\right)}}$

$=\frac{6.657,611-(1,044)(3,778)}{\sqrt{\left(6.189,464-(1,044)^{2}\right)\left(6.24,045,06-(3,778)^{2}\right)}}$

$=\frac{1434}{84870}$

$=0,016$ (Berpengaruh sangat rendah)

Analisis Korelasi X_2 (Ekspansi) terhadap Y (ROI)

\begin{tabular}{|c|c|c|c|c|c|}
\hline $\mathbf{n}$ & $\mathbf{X}_{\mathbf{2}}$ & $\mathbf{Y}$ & $\mathbf{X}_{\mathbf{2}} \cdot \mathbf{Y}$ & $\mathbf{X}_{2}{ }^{2}$ & $\mathbf{Y}^{\mathbf{2}}$ \\
\hline 1 & 559 & 23 & 12,857 & 312.481 & 529 \\
\hline 2 & 567 & 25 & 14,175 & 321.489 & 625 \\
\hline 3 & 570 & 28 & 15,960 & 324.900 & 784 \\
\hline 4 & 682 & 24 & 16,368 & 465.124 & 576 \\
\hline 5 & 684 & 25 & 17,100 & 467.856 & 625 \\
\hline 6 & 716 & 25 & 17,900 & 512.656 & 625 \\
\hline$\Sigma$ & $\mathbf{3 . 7 7 8}$ & $\mathbf{1 5 0}$ & $\mathbf{9 4 , 3 6 0}$ & $\mathbf{2 4 . 0 4 5 . 0 6}$ & $\mathbf{3 , 7 6 4}$ \\
\hline
\end{tabular}

$\mathrm{r}=\frac{n \Sigma \mathrm{X}_{2} Y-\left(\Sigma \mathrm{X}_{2}\right)(\Sigma \mathrm{Y})}{\sqrt{\left(n \Sigma \mathrm{X}_{2}{ }^{2}-\left(\Sigma \mathrm{X}_{2}\right)^{2}\right)\left(n \Sigma Y^{2}-(\Sigma Y)^{2}\right)}}$

$=\frac{6.94,360-(3,778)(150)}{\sqrt{\left(6.24,045,06-(3,778)^{2}\right)\left(6.3,764-(150)^{2}\right)}}$

$=\frac{-540}{3593}$

$=-0,150$ (Berpengaruh sangat rendah dan negatif)

Analisis Keofisien Determinasi

$\mathrm{X}_{1}$ (Modal asing) terhadap $\mathrm{X}_{2}$ (Ekspansi)

Analisis ini bertujuan untuk mengetahui besarnya kontribusi yang diberikan Variabel $\mathbf{X}_{\mathbf{1}}$ (Modal asing) terhadap Variabel $\mathbf{X}_{\mathbf{2}}$ (ekspansi). Untuk mengetahuinya digunakan rumus koefisien determinan.

$$
\begin{aligned}
& \mathrm{Kd}=\mathrm{r}^{2} \times 100 \% \\
& =(0,016)^{2} \times 100 \% \\
& =0,02 \%
\end{aligned}
$$

Dari perhitungan diatas, diperoleh koefisien determinasi sebesar $0,02 \%$ yang berarti "modal asing mempengaruhi ekspansi sebesar $0,02 \%$ dan sisanya $99,98 \%$ dipengaruhi oleh variabel lain yang tidak diteliti seperti modal sendiri."
$\mathrm{X}_{2}$ (Ekspansi) terhadap Y (ROI)

Analisis ini bertujuan untuk mengetahui besarnya kontribusi yang diberikan variabel $\mathrm{X}_{2}$ (Ekspansi) terhadap variabel $\mathrm{Y}$ (ROI). Untuk mengetahuinya digunakan rumus koefisien determinan.

$$
\begin{aligned}
\mathrm{Kd} & =r^{2} \times 100 \% \\
& =(-0,150)^{2} \times 100 \% \\
& =2,25 \%
\end{aligned}
$$

Dari perhitungan diatas, diperoleh koefisien determinasi sebesar 2,25\% yang berarti "Ekspansi mempengaruhi return on investment (ROI) sebesar 2,25\% dan sisanya $97,75 \%$ dipengaruhi oleh variabel lain yang tidak diteliti."

\section{KESIMPULAN DAN SARAN}

\section{Kesimpulan}

Berdasarkan hasil penghitungan dan analisis yang telah dilakukan oleh peneliti selama penelitian dan pembahasan mengenai pengaruh modal asing terhadap ROI melalui ekspansi pada CV. Dani Prima, maka peneliti dapat mengambil kesimpulan sebagai berikut:

1. Modal asing pada CV Dani Prima, yang peneliti analisis berdasarkan dari hasil pembahasan dapat disimpulkan bahwa kondisi modal asing dari tahun 20072013 mengalami kenaikan dan penurunan. Adapun rata-rata perkembangan Modal asing sebesar Rp. 167.185.714 
2. Ekspansi pada CV. Dani Prima, yang peneliti analisis berdasarkan dari hasil pembahasan dapat disimpulkan bahwa perkembangan ekspansi usaha dari tahun 2007-2013 mengalami kenaikan. adapun rata-rata perkembangan ekspansi sebesar Rp. 584.450 .000

3. Return on Invesment (ROI) pada CV. Dani Prima, yang peneliti analisis berdasarkan dari hasil pembahasan dapat disimpulkan bahwa kondisi Return on Invesment (ROI) dari tahun 2007-2013 mengalami kenaikan dan penurunan. Adapun rata-rata perkembangan roi sebesar $25,81 \%$.

4. Seberapa besar pengaruh modal asing terhadap ekspansi pada CV. Dani Prima, dapat dilihat dari hasil perhitungan analisis korelasi (r) variabel modal asing (X1) terhadap Ekspansi (X2), sebagai berikut:

- Dari perhitungan korelasi diatas maka diperoleh hasil koefisien korelasi sebesar 0,428 yang berarti koefisien korelasinya mempunyai hubungan yang sedang dan positif.

- Berdasarkan perhitungan koefisien determinasi maka diperoleh sebesar 18,31\%. Berarti kontribusi yang diberikan modal asing terhadap ekspansi mampu mencapai 18,31\% dan sisanya $81,69 \%$ di pengaruhi faktor lain yang tidak diteliti seperti modal sendiri.
- Berdasarkan hasil Uji hipotesis (t) maka nilai yang diperoleh $t_{\text {hitung }}$ sebesar 0,947 digunakan uji dua pihak, dengan taraf signifikan 5\% dan derajat keabsahan (dk) 6-2 = 4 didapatkan nilai $\mathrm{T}_{\text {tabel }} 2,776$ karena $\mathrm{T}_{\text {hitung }}<$ $\left.\mathrm{T}_{\text {tabel }} 0,947<2,776\right), \operatorname{makaH}_{1^{o}}$ diterima dan $H_{1} a$ ditolak artinya tidak terdapat pengaruh modal asing terhadap ekspansi.

5. Seberapa besar pengaruh ekspansi terhadap return on Invesment (ROI) pada CV. Dani Prima, dapat dilihat dari hasil perhitungan analisis korelasi (r) variabel $\mathrm{X} 2$ terhadap $\mathrm{Y}$, sebagai berikut:

- Dari perhitungan korelasi diatas maka diperoleh hasil koefisien korelasi sebesar 0,108 yang berarti koefisien korelasinya mempunyai hubungan yang sangat rendah dan positif.

- Berdasarkan perhitungan koefisien determinasi maka diperoleh sebesar 1,16\%. Berarti kontribusi yang diberikan ekspansi terhadap return on invesment (ROI) mampu mencapai $1,16 \%$ dan sisanya $98,84 \%$ dipengaruhi faktor lain yang tidak diteliti.

- Berdasarkan hasil Uji hipotesis (t) maka nilai yang diperoleh thitung sebesar 0,217 digunakan uji dua pihak, dengan taraf signifikan 5\% dan derajat keabsahan (dk) 6-2 = 4 didapatkan nilai $\mathrm{T}_{\text {tabel }}$ 2,776 karena 
$\mathrm{T}_{\text {hitung }}<\mathrm{T}_{\text {tabel }}(0,217<2,776)$, maka Tidak adanya pengaruh antara ekspansi $\mathrm{H}_{2} \mathrm{O}$ diterima dan $\mathrm{H}_{2}$ a ditolak artinya terhadap roi pada CV. Dani Prima diharapkan tidak ada pengaruh antara ekspansi dapat lebih memanfaaatkan hubungan terhadap return on invesment.

\section{Saran} variabel tersebut agar perusahaan dapat

Dari kesimpulan diatas, peneliti memperoleh keuntungan yang maksimal dari mengajukan saran kepada pihak CV. Dani Prima yaitu sebagai berikut:

\section{DAFTAR PUSTAKA}

1. Diharapkan CV. Dani Prima dapat memaksimalkan penggunaan modal asing dengan lebih efektif dan efisien guna meningkatkan ekspansi dan roi sehingga perusahaan akan lebih berkembang dari tahun ke tahunnya.

2. Ekspansi pada CV. Dani Prima diharapkan lebih ditingkatkan lagi Karena ekspansi dapat meningkatkan pendapatan pada perusahaan sehingga diharapkan dapat meningkatkan Roi perusahaan.

3. CV. Dani Prima juga diharapkan mampu memaksimalkan profitabilitas (ROI) dari kegiatan operasionalnya agar dapat memberikan keuntungan yang lebih besar untuk perusahaan sehingga perusahaan dapat mempertahankan kelangsungan usahanya.

4. Tidak adanya pengaruh antara modal asing terhadap ekspansi pada CV. Dani Prima diharapkan dapat lebih memanfaaatkan hubungan variabel tersebut agar perusahaan dapat memaksimalkan modal asing secara efektif dan efisien khususnya dari pelaksanaan ekspansi tersebut.

Dasar-Dasar Pembelanjaan

Perusahaan.Yogyakarta. BPFE. 2010.

Husein Umar. Metode penelitian untuk skripsi dan tesis bisnis. Jakarta. Raja Grafindo Persada. 2004.

Jumingan. Analisis Laporan Keuangan. Jakarta. PT Bumi Aksara. 2011.

Kasmir. Pengantar Manajemen Keuangan Jakarta. Kencana. 2008.

Marihot Manullang Dearlina Sinaga. Pengantar Manajemen Keuangan. Yogyakarta. Andi. 2005.

R. Agus Sartono. Manajemen Keuangan Teori dan Aplikasi Yogyakarta. BPFE. 2012.

Suad Husnan. Manajemen Keuangan Teori Dan Penerapan (Keputusan Jangka Panjang). Yogyakarta. BPFE. 2010.

Susan Irawati. Manajemen Keuangan. Bandung. Pustaka. 2006.

Sofyan Syafri Harahap. Analisis Kritis Atas Laporan Keuangan. Jakarta PT Raja Grafindo Persada. 2010.

Sugiyono. Statistika Untuk Penelitian. Bandung. Alfabeta. 2011. 
Sugiyono. Metode Penelitian Kuantitatif

Kualitatif dan $R \& D$. Bandung.

Alfabeta.2013.

Suad Husnan dan Enny Pudjiastuti. Dasar-

Dasar Manajemen Keuangan.

Yogyakarta. UPP STIM YKPN. 2012.

http://repository.unikom.ae.id

http://www.google.com/url?q=http://digilib.

perbanasinstitute.ac.id/index.php\%3Fp

\%3Dshow_detail\%26id\%3D21764\&sa

$=\mathrm{U} \& \mathrm{ei}=\mathrm{U} 5 \mathrm{rzUaW7KcOLiwK} \mathrm{i} 4 \mathrm{DID}$

$\underline{w \& v e d=0 C B M Q F j A F \& u s g=A F Q j C N}$

F1-Qfjm3Ua6VAvaNsdataP11hJZw

http://abstrak.digilib.upi.edu/Direktori/TESI

S/MAGISTER_MANAJEMEN_BISNI

$\underline{\text { S/0809033 AYI_SUBHAN/T_MMB }}$

_0809033_Chapter4.pdf 